\title{
A Case study of Dushta Vrana treated with DurvaTail Vranabasti
}

\author{
Case Study
}

Choudhari Shrikant Jaysing ${ }^{1 *}$, Gadve BN $^{2}$, Lonikar SR $^{3}$

1. PG Scholar (Shalya Tantra), 2. Guide, 3. HOD

Shalya Tantra Department, CSMSS Ayurved Mahavidyalaya, Kanchanwadi, Aurangabad.

\begin{abstract}
"The destruction / break / rupture / discontinuity of body tissue / part of body, is called Vrana." A clean wound in a normal body heals earlier with a minimum scar as compared to contaminated wound. Wound healing is mechanism where the body attempts to restore the integrity of the injured part. Several factors affects the normal process of wound healing such as the site of wound, contamination (foreign bodies/bacterial), local factors like vascular insufficiency or previous radiation, systemic factors such as malnutrition, Disease like diabetes mellitus, Immune deficiencies and medications like steroids. Acharya Sushruta mentioned 60 Upakramas for the management of Vrana and local application of DurvaTail Vrana Basti is one among them. The local application of VranaBasti is one of the best substitutes for of chronic wound healing \& the DurvaTail have better shodhana \& ropana effect. A case report of 34 year - old man, who presented with complaints of an open traumatic ulcer on the dorsum of the right foot associated with pain, discharge, slough, foul smell, oedema and discolouration of the skin has been presented here.
\end{abstract}

Keywords: Dushta vrana, Shodhana \& Ropana, DurvaTail Vranabasti.

\section{INTRODUCTION}

Man, The superior most of all species who always remain in search of one prime goal that is perfect health. Researches are carried out from Vedic era to current age

The wound is biggest challenge to medical profession from Vedic era.

The wound is healed by three way First is primary intention, Second is Secondary intention \& Third is tertiary intention (delayed primary intention). Sometimes the wound refuses or fails to heal, this type of wound is called as Non healing wound. The

*Corresponding Author:

Choudhari Shrikant Jaysing

PG. Scholar (Shalya Tantra)

CSMSS Ayurved Mahavidyalaya,

Kanchanwadi, Aurangabad

Email:-shrikant_choudhari@yahoo.in

Mob. No.: 9421528215
Wound healing process is dependent on several local and general factors [1].

In ayurved literature these Vrana are classified as Sadyo Vrana \& Dushta Vrana [2]. Dushta vrana is formed due to refusal or failure of natural healing process. Acharya Sushruta explained the vrana Chikitsa in Shashti upakramas. In this upakramas local application of medicated oil is one of the most important upakramas [2]. The medicated oil is applicable with different method like Prakshalana, Pichu, Lepa, vranabasti on Dushta Vrana. In this case study local application of DurvaTail is done with Vranabasti. In Vranabasti a wall is erected around the wound with Masha pishti about $2 \mathrm{~cm}$ height $\&$ thickness of about $0.5 \mathrm{~cm}$. In a bowl medicated oil is taken $\&$ warmed on hot water bath till it become lukewarm. This lukewarm oil is poured into the well on the wound by using spoon. When this oil 
get cool it is taken out \& warm oil is poured again. This process is done for $30 \mathrm{~min}$. [3]. In this case study DurvaTail [4] is use as medicated oil \& this DurvaTail have a property of Shodhan \& Ropan so it is more effective in dushtasvrana.

\section{Case Report}

A 34 yrs old male patient presented with the complaints of a non- healing ulcer. Before 2 months he was accidently injured by a steel bar the wound is formed over the dorsum of Right foot. He was treated with Antibiotic ointment (Povidine iodine) by a local doctor but it failed to respond. After few days ulcer become infected with freely flowing pus.

There was no history of DM, HTN or any other major disorder. The family history was also not significant with the patient disorder.

Local Examination:-The floor was covered by slough, edges were inflamed. Ulcer is seen over the dorsum of foot measuring about $7 \times 5 \times 0.5 \mathrm{~cm}$ in dimension with purulent discharge and irregular margin. Tenderness was also present with surrounding indurations and local rise in temperature. Local lymph nodes were not involved. There is no any immunological disorder. Routine haematology and urine investigations were within normal limits.

Every morning the wound was cleaned with the freshly prepared lukewarm Triphala kwatha. After cleaning DurvaTail Vranabasti was locally applied. Dressing was done with the sterile gauze and bandage.

\section{Result}

The clinical features of dushta vrana were improved at the end of First week and the wound was healed completely at the end of $2^{\text {nd }}$ week leaving only a minimal scar Fig. 3. With a follow up for a period of 1months, the patient has shown no signs of recurrence.

\section{Discussion}

- Effect on Vrana Vedana:-Pain and tenderness was completely reduced at the end of treatment. Throbbing pain which was present at the beginning was completely reduced at the end of $1 \mathrm{st}$ week as the purulent discharge decreased because of the shodhana properties of Taila.

- Effect on VranaVarna:-Change in colour occurred when dushta vrana got converted into shuddha, which was due to elimination of doshas out from the body.At the end of 7th day slough was completely reduced and colour of the floor becomes pinkish and healthy granulation tissue appeared.

- Effect on Vrana Strava:-At the end of 2nd week the purulent discharge from the wound completely stopped, this may due to the shodhan and ropan properties of Taila.

- Effect on Vrana Gandha:-Foul smell present at the beginning of treatment was completely reduced at the end of 1 st week. The smell was present because of the pus and as the Vrana becomes shuddha it decreases.

- Effect on Vrana Aakriti:-On 14th day Vrana was completely healed, this may due to Vrana Shodhana property of Taila, which provide ideal environment for healing.

\section{Conclusion}

DurvaTail Vranabsati is the new substitute for Dushata Vrana. It does the action of Shodhan \& Ropan. It is a simple O.P.D level procedure, relatively painless, can do without anaesthesia. Vranabasti will remove only unhealthy granulation tissue, so wound size will not increase. Patient is introduced of new technique in ayurved.

\section{Acknowledgement:-}

The Author is grateful to Department of Shalya Tantra, CSMSS Ayurved Collage \& Research Centre, Kanchanwadi, Aurungabad. 


\section{References}

1) Bailey and Love's Short Practice of Surgery : Edited by Norman S.Williams, Christopher J.K.Bulstrode and P.Ronan O' Connell : Published by London, Hodder Education, 25th Edition-2008, Chapter 3, Pg.No.24-25

2) Sushruta; Sushruta Samhita, Ayurved tatvasandipika,edited by kaviraj Dr.Ambikadatta shastri: Published by Varanasi, Choukambha Surbharati
Prakashan - 2007. Chikitsa Sthana 1/57-58, Pg.No.10.

3) Pankaj B.Patil Dissertation of Rajiv Gandhi University of Health Science Benglore,Karnataka $2011 \quad$ Page No.81(VB GroupApplication)

4) Charak Samhita, Shri Chakrapanivicharit, ayurveddipikavyakhya with yashvanttikesah Vaidyamitra Prakashan-2003 , 701,Sadashiv Peth, Pune.25/92-93,Page No.-563.

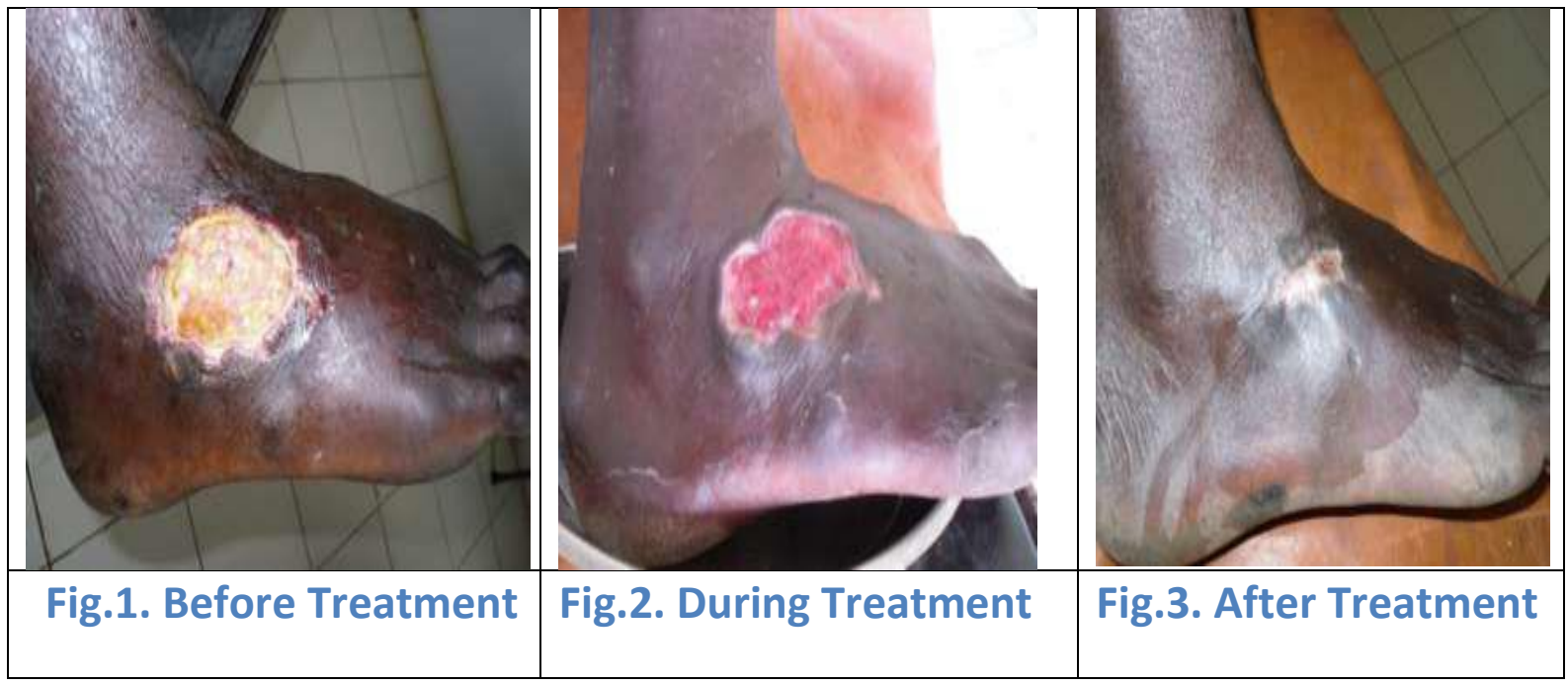

